\title{
Heat flow at the Platanares, Honduras, geothermal site
}

\author{
Joseph G. Meert ${ }^{\mathrm{a}}$ and Douglas L. Smith ${ }^{\mathrm{b}}$ \\ ${ }^{a}$ Department of Geological Sciences, University of Michigan, Ann Arbor, MI 48109, U.S.A. \\ ${ }^{b}$ Department of Geology, University of Florida, Gainesville, FL 32611, U.S.A.
}

(Accepted June 26, 1990)

\begin{abstract}
Meert J.G. and Smith, D.L., 1991. Heat flow at the Platanares, Honduras, geothermal site. In: F.Goff (Editor), Honduras - A Geothermal Investigation. J. Volcanol. Geotherm. Res., 45: 91 - 99.
\end{abstract}

\begin{abstract}
Three boreholes, PLTG-1, PLTG-2 and PLTG-3, were drilled in the Platanares, Honduras geothermal system to evaluate the geothermal energy potential of the site. The maximum reservoir temperature was previously estimated at $225-240^{\circ} \mathrm{C}$ using various types of chemical and isotopic geothermometry. Geothermal gradients of $139-239^{\circ} \mathrm{C} / \mathrm{km}$, calculated from two segments of the temperature-depth profile for borehole PLTG-2, were used to project a minimum depth to the geothermal reservoir of $1.2-1.7 \mathrm{~km}$. Borehole PLTG-1 exhibited an erratic temperature distribution attributed to fluid movement through a series of isolated horizontal and subhorizontal fractures. The maximum measured temperature in borehole PLTG-1 was $150.4^{\circ} \mathrm{C}$, and in PLTG-2 the maximum measured temperature was $104.3^{\circ} \mathrm{C}$. PLTG-3 was drilled after this study and the maximum recorded temperature of $165^{\circ} \mathrm{C}$ is similar to the temperature encountered in PLTG-1.

Heat flow values of $392 \mathrm{mWm}^{-2}$ and $266 \mathrm{mWm}^{-2}$ represent the first directly-measured heat flow values for Honduras and northen Central America. Radioactive heat generation, based on gamma-ray analyses of uranium, thorium and potassium in five core samples, is less than $2.0 \mu \mathrm{Wm}^{-3}$ and does not appear to be a major source of the high heat flow. Several authors have proposed a variety of extensional tectonic environments for western Honduras and these heat flow values, along with published estimates of heat flow, are supportive of this type of tectonic regime.
\end{abstract}

\section{Introduction}

The assessment of geothermal energy resources in Honduras was among the goals of the Central American Energy and Resources Project sponsored by the United States Agency for International Development. A cooperative effort among the Honduras Empresa Nacional de Energia Electrica, the United States Geological Survey, and the Los Alamos National Laboratory identified six potential geothermal sites in Honduras (Goff et al., 1987a). Geochemical investigations indicated that the Platanares site (Fig. 1) was the most promising area for geothermal resource exploration, and three boreholes, PLTG-1, PLTG-2, and PLTG-3, were drilled in late 1986 and early 1987 to evaluate the potential of the site.

Heat flow computations, based on on-site field measurements of temperature values in the first two holes and subsequent laboratory analyses of thermal conductivity values, were conducted in March, 1987, and are reported herein. These represent the first directlymeasured heat flow determinations for Honduras and the only values known for the northern half of Central America. 


\section{Regional heat flow}

The closest locations to western Honduras of previously determined heat flow values are in Mexico. Ziagos et al. (1985) reported several values for the Trans-Mexico volcanic belt which average $91 \mathrm{mWm}^{-2}$, and two values in northernmost Mexico which are 17 $\mathrm{mWm}^{-2}$ and $45 \mathrm{mWm}^{-2}$. Sass et al. (1974) presented values for twelve sites in eastern Panama and northwestern Colombia. The highest values, averaging $76 \mathrm{mWm}^{-2}$, were near the southern terminus of the Central American volcanic arc. Other values, to the east and away from the volcanic region, are lower $\left(29-46 \mathrm{mWm}^{-2}\right)$. Eckstein et al.
(1985) reported an area of elevated geothermal gradients near the Momotombo volcano in southwestern Nicaragua. Measurements in the Cordillera de Guanacaste of Costa Rica (Blackwell et al., 1977) yielded an average heat flow value of $60 \mathrm{mWm}^{-2}$ which was presented as the background heat flux for that part of the Central American volcanic arc. Measurements in the Miravalles hydrothermal system, in the same area of Costa Rica, suggested heat flow in excess of $500 \mathrm{mWm}^{-2}$. Following the methods of Swanberg (1979) and Swanberg and Morgan (1979), Goff et al. (1987a) used the silica content of cool groundwaters in Honduras to empirically estimate heat flow. A background heat flux of approx-

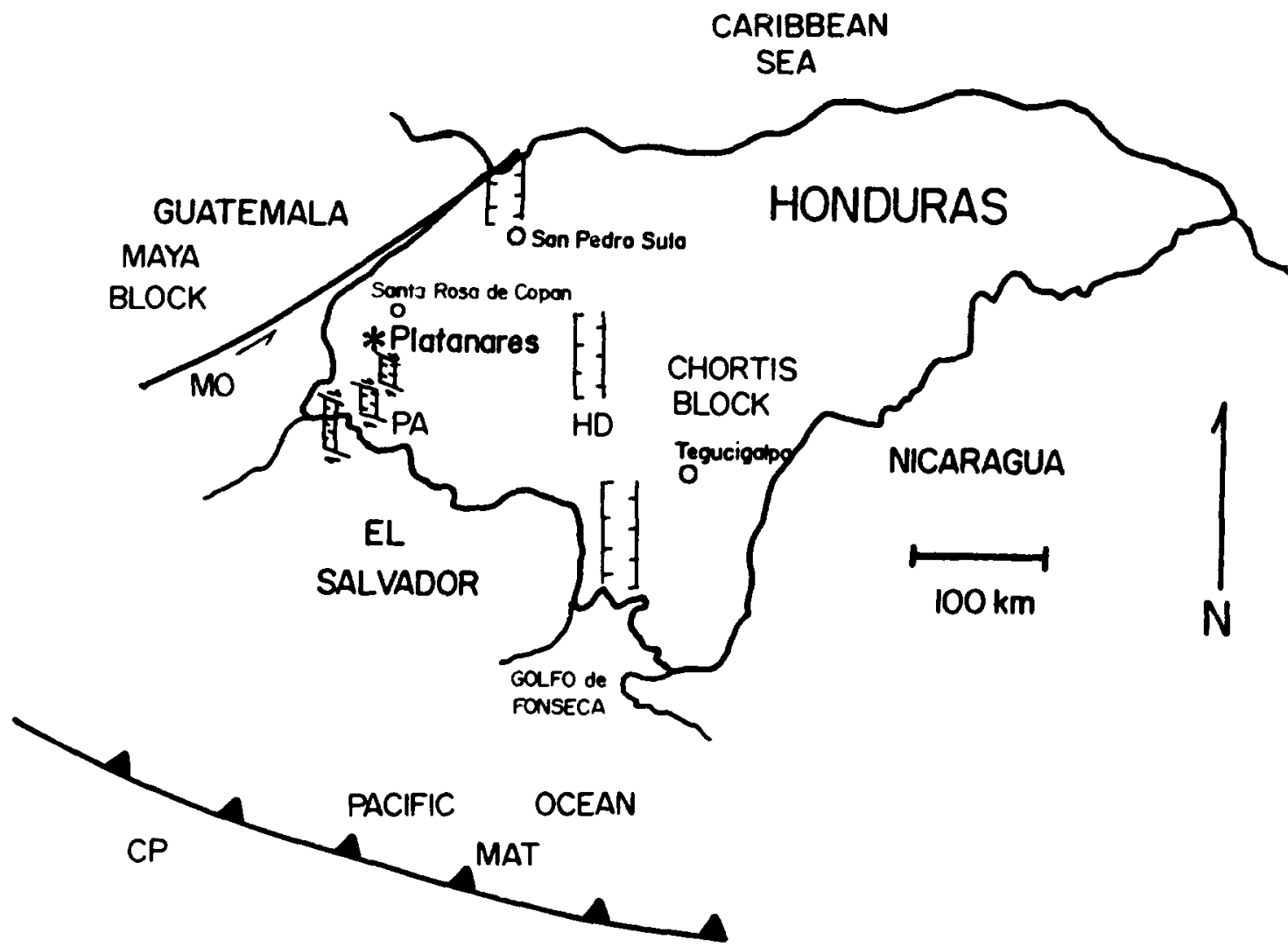

Fig. 1. Map of Honduras showing the Platanares Geothermal site, the Honduras Depression $(H D)$, the Motagua fault zone $(M O)$, the Middle America Trench $(M A T)$, the Cocos Plate $(C P)$, and three proposed pull-apart basins $(P A)$ near the Platanares site (Manton, 1987). 
imately $120 \mathrm{mWm}^{-2}$ was calculated for Honduras.

Conditions for anomalously-high heat flow are prevalent in western Honduras despite the lack of recent volcanism. Honduras is situated on the Chortis block (Anderson and Schmidt, 1983) which forms part of the western margin of the Caribbean plate (Fig. 1). The northwestern wedge of the Chortis block is subjected to shearing stresses created by the movement of the adjacent Cocos and North American plates. A series of graben-like valleys, described as the Honduras Depression, trends north - south through western Honduras from the Golfo de Fonseca to the Caribbean sea (Fig. 1). This feature, associated with Quaternary extensional tectonics, Quaternary basaltic volcanism, and widespread hot springs, is attributed to a rotation of the trailing edge of the Caribbean plate and the interaction of crustal blocks above the Cocos plate subduction zone. Manton (1987) disputes the existence of a Honduras Depression and suggests that the features are more representative of pull-apart basins and therefore related to strike-slip faulting rather than rifting.

The Platanares geothermal site is located in western Honduras within the rotated plate wedge west of the Honduras Depression. Replete with fault-controlled thermal springs, the region is in the mountainous Cerras los Tablones west of Santa Rosa de Copan (Fig. 1). Goff et al. (1987a, b) and Heiken et al. (1991-this volume), have described the local stratigraphy and structural features as a thin veneer of Quaternary alluvium and stream gravels overlying a thick sequence of the

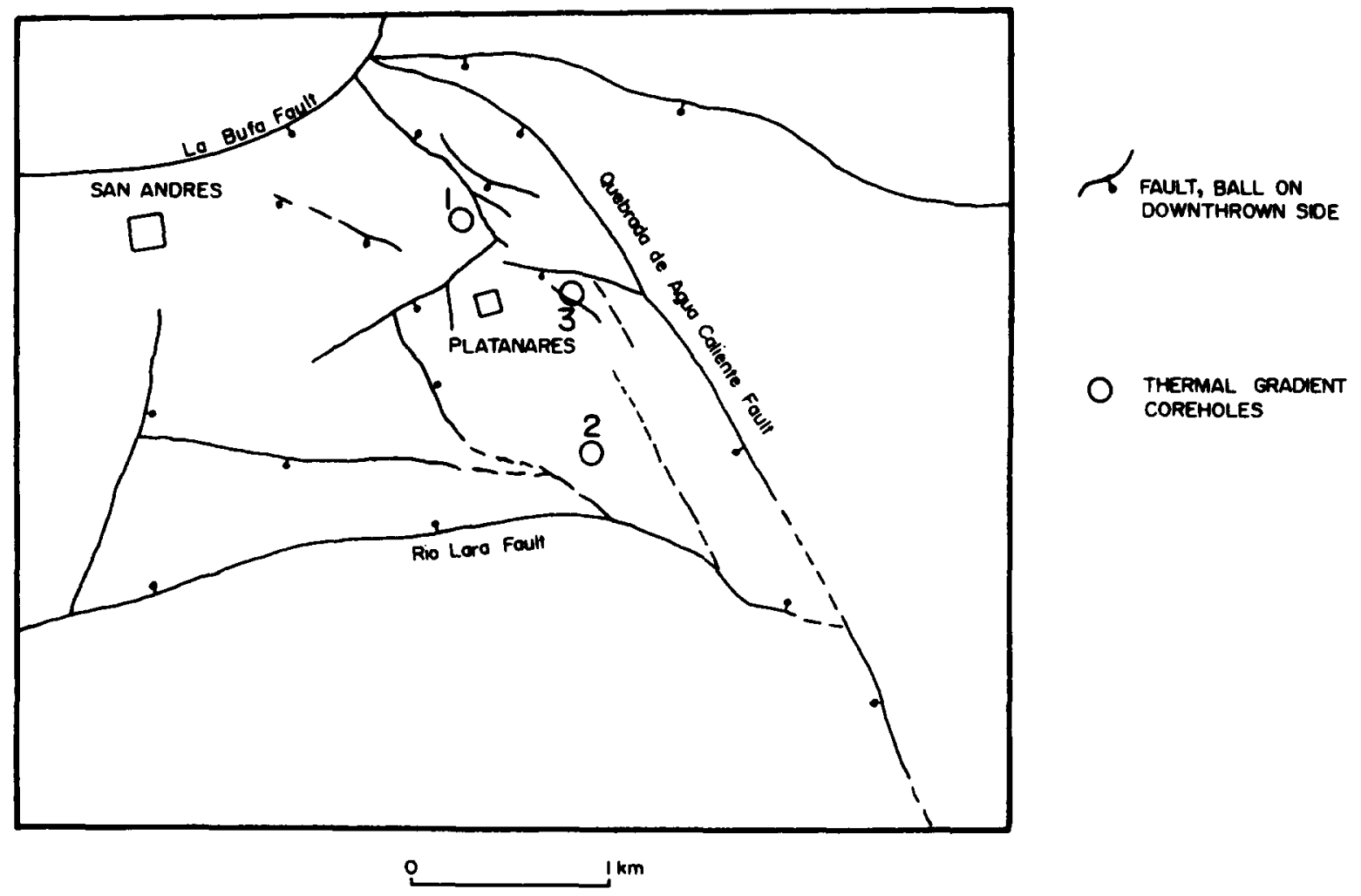

Fig. 2. Map of the Platanares geothermal site showing the locations of PLTG-1, PLTG-2, and PLTG-3 coreholes and major faults (from Heiken et al., 1991-this volume). 
Miocene Padre Miguel Group. This widespread unit contains primarily silicic tuffs and lava flows, both of which are locally fractured and hydrothermally altered. Beneath the Padre Miguel Group is the Miocene Subinal Formation (?) of red beds, and the Oligocene Matagalpa Formation which is composed primarily of andesitic lava flows (Heiken et al., 1991-this volume). Beneath the Tertiary rocks lies red beds of the Valle de Angeles Group of Cretaceous to Eocene age. The dominant basement rock of the region is described as Paleozoic (?) schist by Heiken et al. (1986).

Borehole PLTG-1 was drilled along a major NW-trending fault zone and associated thermal springs (Fig. 2). The borehole penetrated approximately $560 \mathrm{~m}$ of severely altered andesitic lavas of the Matagalpa Formation and bottomed in $90 \mathrm{~m}$ of the Valle de Angeles red beds. PLTG-2, approximately one kilometer to the southeast of PLTG-1, penetrated $310 \mathrm{~m}$ of silicic tuffs and altered volcanoclastics of the Padre Miguel Group bottoming in $90 \mathrm{~m}$ of the Subinal Formation (?) red beds (Heiken et al., 1991-this volume). PLTG-3, located $680 \mathrm{~m}$ to the south of PLTG-1, extended through the Padre Miguel Group, the Subinal Formation (?), the Matagalpa Formation, and the Valle de Angeles Group.

\section{Temperature gradients}

Temperature measurements were made in both the PLTG-1 and PLTG-2 boreholes with a platinum resistance thermometer encased in

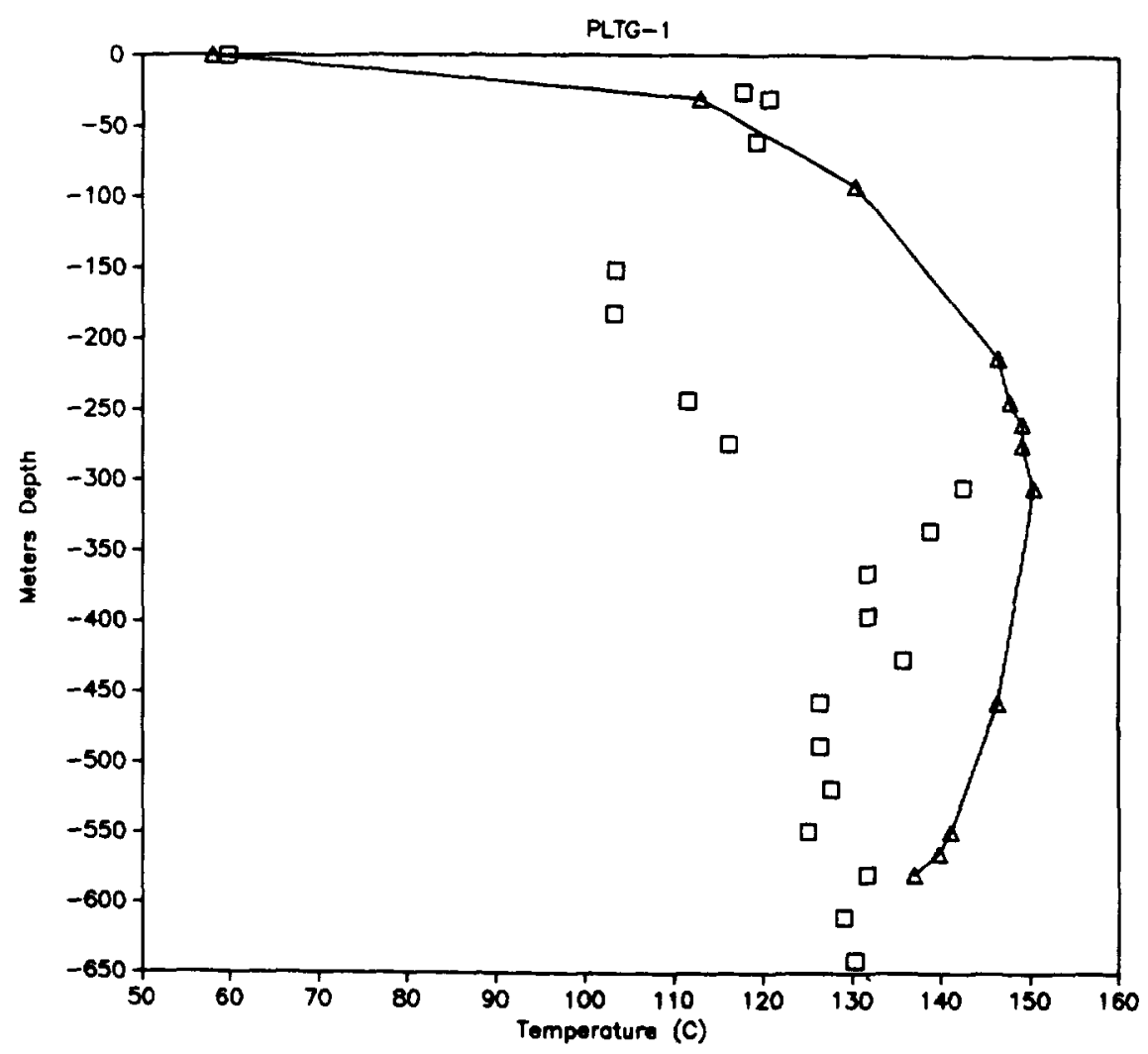

Fig. 3. Temperature-depth profile for the PLTG-1 borehole. Squares represent measurements taken during the descent phase and triangles represent measurements during the ascent of the probe. The temperature inversion is outlined in the ascent temperature values. 
a weighted probe and coupled by a fourconductor shielded cable to a Mueller-type wheatstone bridge. The probe was constructed specifically for high-temperature studies in caustic environments and was calibrated and tested in constant temperature thermal baths and ovens. Measurements were made at discrete intervals during the descent and ascent of the probe. Depths were assigned according to a counter wheel through which the cable passed and verified with markers in place on the cable.

Figures 3 and 4 show the temperature-depth profiles for each borehole. PLTG-3 was not drilled at the time of this study, however, measurements using a Kuster tool indicated nearly isothermal conditions in the bore with a temperature maximum of $165^{\circ} \mathrm{C}$. Measure- ments in PLTG-1 failed to exhibit an easily discernible temperature gradient. Two distinct linear trends are apparent for PLTG-2. The temperature values for PLTG-2 were corrected for topographic effects using the procedure described by Birch (1950), and leastsquares gradients were computed. The upper temperature gradient $(13-150 \mathrm{~m})$ was $239 \pm 0.88^{\circ} \mathrm{C} / \mathrm{km}(r=0.995)$ and the lower portion of the hole $(170-400 \mathrm{~m})$ yielded a gradient of $139.1 \pm 0.42^{\circ} \mathrm{C} / \mathrm{km}(r=0.998)$. The uncorrected values were approximately $3 \%$ lower. The maximum recorded temperature in PLTG-2 was $104.26^{\circ} \mathrm{C}(400 \mathrm{~m})$. PLTG-2 was cased to total depth and apparently was not subjected to the turbulent flows which distorted the gradient for PLTG1.

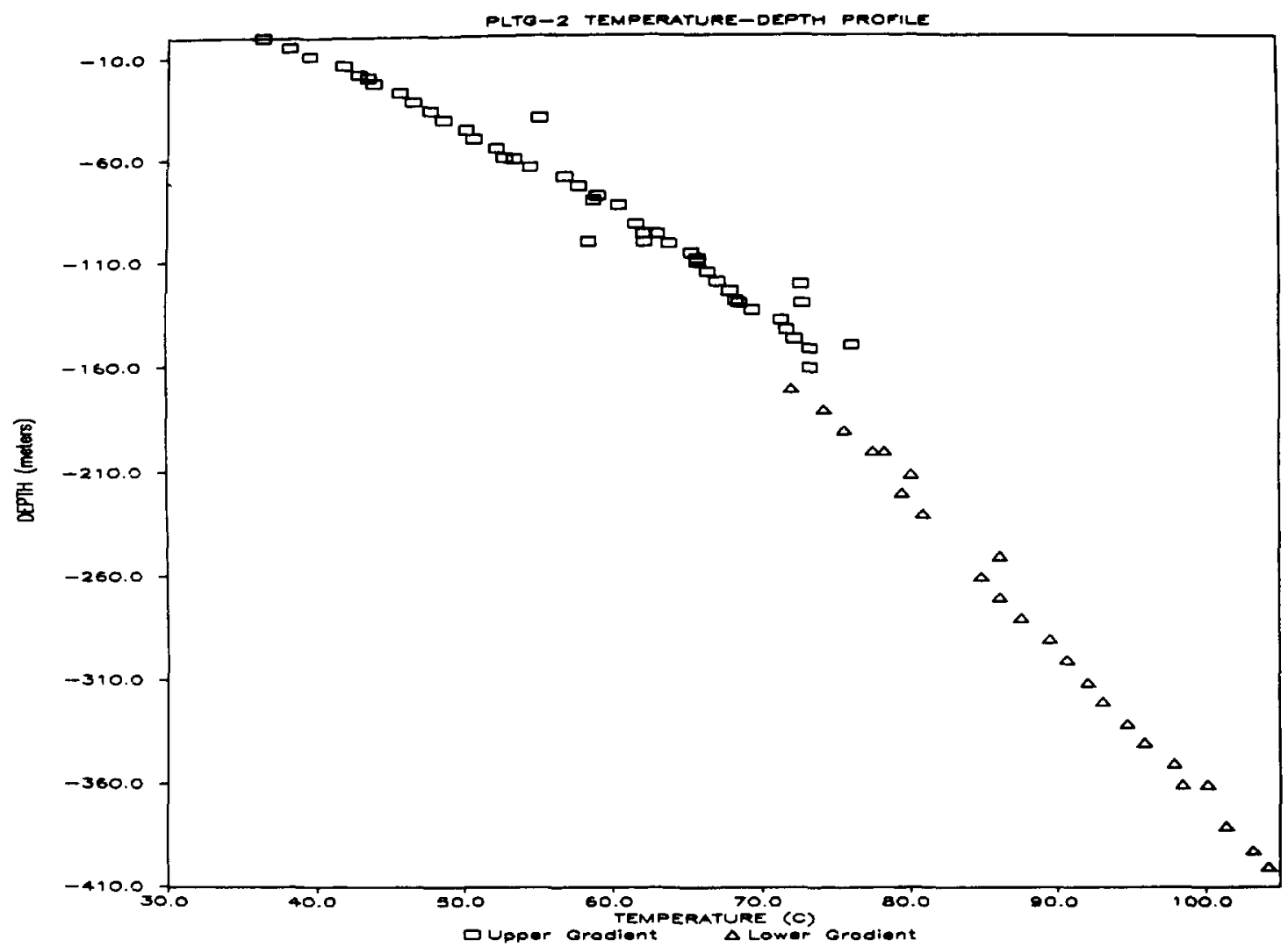

Fig. 4. Temperature-depth profile of the PLTG-2 borehole. Squares represent the measurements used for calculating the upper gradient $\left(239.0^{\circ} \mathrm{C} / \mathrm{km}\right)$ and triangles represent the measurements used to calculate the lower gradient $\left(139.1^{\circ} \mathrm{C} / \mathrm{km}\right)$. 
The two linear temperature-depth trends appear to be independant of lithology as no temperature gradient contrasts are observed at the red bed - volcanic rock boundary (see Fig. 4). The locus of the gradient change may mark a zone of former water entry within a highly fractured zone.

The erratic temperature distribution in PLTG-1 may be caused by the relatively high well-head pressure (96 psig, Goff et al., 1987b) and turbulent flow within the water column of the well. A prolonged series of flow tests ( $\approx 20$ days) conducted immediately prior to the logging procedure may have heated the upper $75 \mathrm{~m}$ of the borehole beyond its natural temperature. Each time the probe was lowered within the borehole, the well head valve was opened, and a small steam blowoff occurred. A fracture zone at $250 \mathrm{~m}$ depth that produced hot fluid before being cemented off, and a possible zone of saturated vapor pressure at $300-350 \mathrm{~m}$ depth (Bargar, 1987) yielded the hottest temperatures $\left(150.4^{\circ} \mathrm{C}, 305 \mathrm{~m}\right)$ in the well. A major zone of water entry at $625-640$ $m$ depth did not yield higher temperatures at those depths. Earlier measurements, using a Kuster tool, however, detected temperatures of $160^{\circ} \mathrm{C}$ from $300 \mathrm{~m}$ to total depth (Goff et al., 1987b). Truesdell et al. (1987) estimated subsurface temperatures, using enthalpy measurements during flow tests, of approximately $157^{\circ} \mathrm{C}$.

A significant variation existed between the ascent and descent temperature profiles (Fig. 3) for PLTG-1. This may be attributable to a disturbance within the well during the measurement process. Alternatively, a heat sink-source response was possible from a 60 $\mathrm{cm}$-long metal pipe affixed to the probe to counter the excess pressures within the borehole.

The temperature-depth profile of PLTG-1 does, however, resemble temperature-depth profiles from the Momotombo, Nicaragua, geothermal field (Eckstein et al., 1985). Eckstein et al. (1985) explain the temperature variations as being the result of isolated, variable-temperature fluid flow through a series of horizontal and subhorizontal feeder fractures. Such a situation could be invoked to explain the profile of PLTG-1. The borehole is located near two major intersecting normal faultlines which are considered to be the main feeders to the horizontal and subhorizontal "aquifer" fractures. This configuration may have allowed a silica-cap to precipitate along a "cold" water, "hot" water interface. A zone of former water entry at $252 \mathrm{~m}$ depth correlates closely with the maximum measured temperatures in the borehole $\left(\approx 150^{\circ} \mathrm{C}\right.$ from $244-305 \mathrm{~m})$. The temperature-depth profile inverts to a lower temperature zone at the bottom of the well $\left(130^{\circ} \mathrm{C}\right.$ at $\left.640.2 \mathrm{~m}\right)$. Thus, the upper zone represents the "hot" water interface and the lower zone represents the source of the "cold" water. More data are clearly needed to test this explanation of the profile.

\section{Thermal conductivity}

Representative samples were obtained from drillers' core for both PLTG-1 and PLTG-2. Thermal conductivity values were determined in laboratory measurements on machined samples using standard divided-bar techniques as described by Lee (1965). Calibration was accomplished with fused quartz and natural quartz standards. Soft and/or friable samples were unable to endure the compressive stresses in the divided-bar apparatus and, consequently, were crushed and analyzed as fragments in copper cells following the procedure described by Sass et al. (1971). Porosity values of $8 \%$ and $15 \%$ were assigned to the volcanic and red bed samples, respectively, after values obtained by Keller (1960) and Davis (1969). The variation of up to $15 \%$ from these assigned values does not significantly alter the results. The in-situ temperatures could not be simulated using the divided-bar apparatus and a temperature correction (Birch and Clark, 1947 ) indicated an insignificant variation from 
measured conductivities.

Tables 1 and 2 show the results of the thermal conductivity measurements. The mean harmonic thermal conductivity for the upper portion of PLTG-2 $(13-150 \mathrm{~m})$ is $1.64 \pm 0.19$ $\mathrm{Wm}^{-1}{ }^{\circ} \mathrm{C}^{-1}$ while the lower portion $(170-400 \mathrm{~m})$ has a value of $1.91 \pm 0.30$ $\mathrm{Wm}^{-1}{ }^{\circ} \mathrm{C}^{-1}$. The mean harmonic conductivity for PLTG-1 is $2.15 \pm 0.32 \mathrm{Wm}^{-1}{ }^{\circ} \mathrm{C}^{-1}$. Borehole PLTG-1 is characterized by andesitic and sedimentary rocks which have been subjected to hydrothermal alteration, whereas PLTG-2 penetrates less conductive silicic tuffs and sedimentary rocks. Thermal conductivity values for the red beds in both holes are similar to the volcanic rocks indicating that hydrothermal alteration has a pronounced effect on the thermal conductivity of the sedimentary rocks.

\section{TABEL 1}

Conductivity values for PLTG-1 borehole

\begin{tabular}{lcll}
\hline $\begin{array}{l}\text { Sample } \\
\mathrm{Nr} .\end{array}$ & $\begin{array}{l}\text { Depth } \\
(\mathrm{m})\end{array}$ & $\begin{array}{l}\text { Conductivity } \\
\left(\mathrm{W} \mathrm{m}^{-1}{ }^{\circ} \mathrm{K}^{-1}\right)\end{array}$ & \begin{tabular}{l} 
Description \\
\hline $20-1$
\end{tabular} \\
\hline 52 & 1.91 & Andesite* \\
$50-18$ & 101 & 1.97 & Andesite* \\
$60-6$ & 159 & 2.66 & Andesite** \\
$70-5$ & 203 & 2.26 & Andesite* \\
$82-11$ & 246 & 1.71 & Andesite* \\
$100-6$ & 394 & 2.36 & Andesite* \\
$110-5 \mathrm{f}$ & 412 & 2.30 & Andesite* \\
$145-1 \mathrm{~b}$ & 459 & 2.57 & Andesite** \\
$135-3$ & 515 & 2.41 & Andesite** \\
$145-6$ & 560 & 2.47 & Andesite** \\
$155-6$ & 601 & 1.57 & Red shale** \\
\hline
\end{tabular}

* Hydrothermally altered.

** Severe hydrothermal alteration.

Alteration minerals include pyrite, calcite, quartz and flourite as reported by Goff et al. (1987a).

Mean harmonic conductivity $\left(\mathrm{Wm}^{-10} \mathrm{~K}^{-}\right)=2.15 \pm$ 0.36 . Mean conductivity $\left(\mathrm{W} \mathrm{m}^{-10} \mathrm{~K}^{-1}\right)=2.20 \pm 0.33$.

Porosity estimates for volcanic rocks $=8 \%$.

Porosity estimates for red shales and siltstones $=15 \%$.

\section{Radioactive heat generation}

Several one-kilogram composite samples of volcanic rock were prepared from core specimens for analyses in a gamma-ray spectrometer to determine the relative abundances of the heat producing radioelements uranium, thorium and potassium. The samples were crushed, weighed, then sealed in airtight plexiglass containers and allowed to equilibrate for one month prior to measurement. The detection

\section{TABLE 2}

Conductivity values for PLTG-2 borehole

\begin{tabular}{llll}
\hline $\begin{array}{l}\text { Sample } \\
\text { No. }\end{array}$ & $\begin{array}{l}\text { Depth } \\
(\mathrm{m})\end{array}$ & $\begin{array}{l}\text { Conductivity } \\
\left(\mathrm{W} \mathrm{m}^{-1} \mathrm{~K}^{-1}\right)\end{array}$ & \begin{tabular}{l} 
Description \\
\hline $17-2$
\end{tabular} \\
\hline 51 & 1.96 & Volcaniclastic* \\
$26-4$ & 76 & 1.48 & Volcaniclastic* \\
$34-1$ & 102 & 1.45 & Silicic tuff* \\
$39-8$ & 127 & 1.49 & Silicic tuff* \\
$40-15$ & 135 & 1.64 & Silicic tuff* \\
$46-2$ & 155 & 1.68 & Volcaniclastic* \\
$50-11$ & 173 & 1.90 & Silicic tuff* \\
& & 1.55 & Volcaniclastic* \\
$56-7$ & 200 & 2.05 & Silicic tuff* \\
$61-14$ & 224 & 1.52 & Silicic tuff* \\
$68-6$ & 252 & 2.19 & Silicic tuff* \\
$74-5$ & 276 & 1.84 & Silicic tuff* \\
$80-3$ & 302 & 1.63 & Silicic tuff* \\
$80-9$ & 304 & 2.07 & Red silstone* \\
$84-27$ & 323 & 2.43 & Red shale* \\
$92-9$ & 352 & 2.30 & Red shale* \\
$96-28$ & 373 & 1.97 & Red siltstone* \\
103 & 400 & & \\
\hline
\end{tabular}

* Slight hydrothermal alteration.

Alteration minerals include pyrite, calcite, quartz and flourite as reported by Goff et al. (1987a).

Upper portion $(50-173 \mathrm{~m})$ :

Mean harmonic conductivity $\left(\mathrm{W} \mathrm{m}^{-10} \mathrm{~K}^{-1}\right)=1.64 \pm$ 0.18

Mean conductivity $\left(\mathrm{W} \mathrm{m}^{-1}{ }^{\circ} \mathrm{K}^{-1}\right)=1.66 \pm 0.19$.

Lower portion $(200-400 \mathrm{~m})$ :

Mean harmonic conductivity $\left(\mathrm{W} \mathrm{m}^{-10} \mathrm{~K}^{-1}\right)=1.91 \pm$ 0.30

Mean conductivity $\left(\mathrm{W} \mathrm{m}^{-10} \mathrm{~K}^{-1}\right)=1.96 \pm 0.30$.

Porosity estimates for volcanic rocks $=8 \%$.

Porosite estimates for red shales and siltstones $=15 \%$. 
system consists of a six-inch diameter $\mathrm{NaI}$ (TI) crystal and photomultiplier tube enclosed in a four-inch lead brick housing.

Table 3 shows the individual radioelement abundances for each sample analyzed in the gamma-ray spectrometer. The resultant heat production values are $1.3 \mu \mathrm{Wm}^{-3}$ for PLTG-1 and $2.0 \mu \mathrm{Wm}^{-3}$ for PLTG-2. These values, while representing less than one kilometer of surficial volcanic rocks, suggest a relatively insignificant amount of crustal heat generation if they are indicative of the upper lithosphere in this area.

\section{Conductive heat flow}

One-dimensional conductive heat flow can be calculated from the product of the mean harmonic thermal conductivity and the geothermal gradient. Heat flow for the PLTG-2 borehole is calculated as $392 \pm 45 \mathrm{mWm}^{-2}$ for the depth range $13-150 \mathrm{~m}$ and $266 \pm 41 \mathrm{mWm}^{-2}$ for the depth range $170-400 \mathrm{~m}$. The value for the lower portion of the borehole is more significant, but is interpreted as identifying heat which has been conveyed upward by convective transport in addition to that conducted through the crust.

Geochemical data (Goff et al., 1987b) indicate a maximum reservoir temperature of $220-240^{\circ} \mathrm{C}$. The lower temperature gradient in
PLTG-2, if extrapolated downward without disruption, suggests a probable depth of $1.2-1.7 \mathrm{~km}$ to the reservoir beneath PLTG-2. Fault-controlled fluid transport in the area diminishes the probability of a constant temperature gradient and these depths should be regarded as minima.

\section{Summary and conclusions}

The two boreholes logged in this study, PLTG-1 and PLTG-2, have yielded the first directly-measured values of temperature and heat flow in Honduras. The values 266 $\mathrm{mWm}^{-2}$ (PLTG-2 lower portion) and 392 $\mathrm{mWm}^{-2}$ (PLTG-2 upper portion), along with an empirically derived heat flow estimate of 120 $\mathrm{mWm}^{-2}$ (Goff et al., 1987a) are indicative of a thermally active region. The anomalously high heat flow is consistent with the expected thermal expression for tectonic rifting which has been proposed for western Honduras, but does not preclude an origin of the Honduras Depression through strike-slip motion.

Radioactive heat generation is relatively insignificant and implies that the anomalous heat flow is attributable to tectonic instability and convective transport of heat in a localized hydrothermal system. Linear temperature gradients in the PLTG-2 borehole suggest a depth to the source reservoir of $1.2-1.7 \mathrm{~km}$, assum-

\section{TABLE 3}

Heat production in PLTG-1 and PLTG-2

\begin{tabular}{lcllllll}
\hline Hole & Sample & $\begin{array}{l}\text { Depth } \\
(\mathrm{m})\end{array}$ & $\begin{array}{l}\mathrm{U} \\
(\mathrm{ppm})\end{array}$ & $\begin{array}{l}\text { Th } \\
(\mathrm{ppm})\end{array}$ & $\mathrm{K} \%$ & Description $\begin{array}{l}\mathrm{H} . \mathrm{P} . \\
\left(\mu \mathrm{W} \mathrm{m}^{3}\right)\end{array}$ \\
\hline 1 & $60-6$ & 203 & 2.12 & 6.95 & 2.625 & Andesite & 1.29 \\
1 & $135-3$ & 515 & 2.43 & 6.82 & 2.746 & Andesite & 1.38 \\
2 & $40-15$ & 135 & 3.33 & 8.71 & 3.178 & Tuff & 1.78 \\
2 & $68-6$ & 252 & 3.86 & 12.86 & 2.190 & Tuff & 2.13 \\
2 & $80-3$ & 302 & 4.10 & 12.83 & 0.883 & Tuff & 2.07
\end{tabular}

Mean heat production in PLTG-1 $=1.31 \mu \mathrm{W} \mathrm{m}^{-3}$.

Mean heat production in PLTG-2 $=2.00 \mu \mathrm{W} \mathrm{m}^{-3}$. 
ing a maximum temperature of $240^{\circ} \mathrm{C}$, and no disturbance of the gradient below $400 \mathrm{~m}$. PLTG-1 displays an erratic temperature profile which has been correlated to a similar system in the Momotombo, Nicaragua geothermal field and can be interpreted as arising from the isolated flow of variable temperature fluids through the borehole.

\section{Acknowledgements}

This research was supported by a grant from the Los Alamos National Laboratory (5-XSH42576-1). We are indebted for field assistance to Heinz Rufenacht and the drillers of Swissboring, Guatemala City; to Napoleon Ramos of ENEE, Tegucigalpa, for a generous allotment of core samples for laboratory work; to Fraser Goff of Los Alamos National Laboratory for field assistance and a critical review of the manuscript; and to two anonymous reviewers for several helpful suggestions on the manuscript.

\section{References}

Anderson, T.H. and Schmidt, V.A., 1983. The evolution of Middle America and the Gulf of Mexico-Caribbean Sea during Mesozoic time. Geol. Soc. Am. Bull., 94: $941-966$.

Bargar, K., 1987. Fluid inclusion data for drill hole PLTG1, Platanares geothermal area, Honduras. Geotherm. Res. Counc. Trans., 11: 225-229.

Birch, F., 1950. Flow of heat in the Front Range, Colorado. Geol. Soc. Am. Bull., 61: 537-630.

Birch, F. and Clark, H, , 1947. The thermal conductivity of rocks and its dependence upon temperature and composition, Parts I and II. Am. J. Sci., 238: 529-558, $613-635$

Blackwell, D.D., Granados, E. and Koenig, J.B., 1977. Heat flow and geothermal gradient exploration in the Cordillera de Guanacaste of Costa Rica. Geotherm. Resour. Counc. Trans., 1: 17-18.

Davis, S.N., 1969. Porosity and permeability in natural materials. In: R.J.M. De Weist (Editor), Flow Through Porous Media. Academic Press, New York, N.Y., pp. 53-69.

Eckstein, Y., Maurath, G. and Ferry, R.A., 1985. Modeling the thermal history of an active geothermal system. J. Geodyn., 4: $149-163$.

Goff, F.E., Janik, C.J., Gutierrez, J.W., Truesdell,
A.H., Shevenell, L.A., Trujillo, P.E., Grigsby, C.O., Paredes, J.R. and Counce, D.A., 1987a. Hydrogeochemical investigation of six geothermal sites in Honduras, Central America. Los Alamos National Laboratory report \# LA-10785-MS, 170 pp.

Goff, F.E., Shevenell, L., Kelkar, S., Smith, D., Meert, J., Heiken, G., Bargar, K., Ramos, N., Truesdell, A.H., Stallard, M. and Musgrave, J., 1987b. Stratigraphy, temperature profiles, and flow test data from PLTG-1 and PLTG-2 coreholes, Platanares geothermal system, Honduras. Geotherm. Resour. Counc. Trans., 11:253-260.

Heiken, G., Eppler, D., Wohletz, K., Flores, W., Ramos, N. and Ritchie, A., 1986. Geology of the Platanares geothermal site, Copan, Honduras. Los Alamos National Laboratory report \#LA-10634-MS.

Heiken, G., Ramos, N., Duffield, W., Musgrave, J., Wohletz, K., Priest, S., Aldrich, J., Flores, W., Ritchie, A., Goff, F., Eppler, D. and Escobar, C., 1991. Geology of the Platanares geothermal Area, Departamento de Copan, Honduras. J. Volcanol. Geotherm. Res., 45: 41-58.

Keller, G.V., 1960. Physical properties of the tuffs in the Oak Spring Fm., Nevada. U.S. Geol. Surv. Prof. Pap. 400-B.

Lee, W.H.K. (Editor), 1965. Terrestrial Heat Flow. Geophys. Monogr. Ser. Vol. 8, AGU, Washington, D.C.

Manton, W.I., 1987. Tectonic interpretation of the morphology of Honduras. Tectonics, 6(5): 633-651.

Sass, J.H., Munroe, R.J. and Moses, J.H., 1974. Heat flow from eastern Panama and northwestern Colombia. Earth Planet. Sci. Lett., 23: 43-52.

Sass, J.H., Lachenbruch, A.H. and Munroe, R.J., 1971. Thermal conductivity of rocks from measurements on fragments and its application to heat flow determinations. J. Geophys. Res., 76: $3391-3401$.

Swanberg, C.A., 1979. Chemistry of thermal and nonthermal groundwaters in the Rio Grande Rift and adjacent tectonic provinces. In: R.E. Rieker (Editor), Rio Grande Rift: Tectonics and Magmatism. AGU, Washington, D.C., pp. $279-288$.

Swanberg, C.A. and Morgan, P., 1979. The linear relation between temperature based on silica content of groundwater and regional heat flow: A new heat flow map of the United States. Pure Appl. Geophys., 117: $227-241$

Truesdell, A.H., Stallard, M.L., Trujillo, P.E., Counce, D., Winnet, T., Goff, F. and Shevenell, L., 1987. Interpretation of fluid chemistry from the PLTG-1 exploratory drillhole, Platanares, Honduras. Geotherm. Res. Counc. Trans., 11: pp 217-222.

Ziagos, J.P., Blackwell, D.D. and Mooser, F., 1985. Heat flow in southern Mexico and the thermal effects of subduction. J. Geophys. Res., 90: 5410 - 5420. 